\title{
Kasusdistribution i personlige pronomener i danske, franske og italienske paratagmer
}

\section{Eva Skafte Jensen, Kirsten Jeppesen Kragh \& Erling Strudsholm}

\begin{abstract}
This paper presents a study on the distribution of case forms of personal pronouns in coordinated conjuncts in the three languages Danish, French and Italian. All three are so-called 'case-poor' languages, and all three operate with small and well defined sets of case forms in personal pronouns. However, investigations based on large corpora reveal that the principles governing the distribution of case forms only to some extent are the same. Furthermore, similarities and differences do not necessarily follow 'genealogical' lines, but transcend these, e.g. in some cases Danish and Italian show larger similarities than for instance French and Italian. Finally, this particular domain (case distribution in personal pronouns) is subject to strong prescriptive forces, and this, too, has bearing on the distribution.
\end{abstract}

Nøgleord: kasusdistribution, personlige pronomener, dansk, fransk, italiensk

\section{Indledning}

Fælles for de tre sprog dansk, fransk og italiensk er at de alle har rester af et tidligere udbygget kasussystem bevaret i de personlige pronomener og stort set kun her; de er med andre ord 'kasusfattige' sprog (Sigurðsson 2006). De rester af tidligere tiders kasussystemer man kan iagttage i de tre sprog, ligner i visse tilfælde hinanden, i andre tilfælde er der store forskelle, og dette er naturligvis interessant at undersøge nærmere.

I alle tre sprog er kasusvalget ikke kun betinget af syntaktisk funktion, men også af andre faktorer som person, numerus og informationsstrukturelle 
forhold. I denne artikel vil vi særligt koncentrere os om kasusdistributionen i paratagmer hvor mindst en af de sideordnede konstituenter er et personligt pronomen ( $\mathrm{x}$ da. ham og hans kone, fr. Foséphine et toi ('Josefine og dig'), it. io e te ('jeg og dig')). Et paratagme er et komplekst opbygget syntagme hvor der foreligger sideordning mellem de respektive konstituenter (jf. Diderichsen 1952; Hansen \& Heltoft 2011: 281-282). I tilgift til de faktorer som allerede er nævnt, ser det ved paratagmerne ud til at også rækkefølge er relevant at inddrage i analysen. Dette gælder bl.a. i paratagmer med det som Parrott (2009) kalder 'mismatch', altså paratagmer hvor to sideordnede pronomener ikke står i samme kasus (fx da. ham og jeg, it. io e te ('jeg og dig')). Rækkefølge spiller tilsyneladende også en rolle i samspillet med en faktor som person; placeringen af personlige pronomener som første eller andet sideordnede led er fx forskellig alt efter om der er tale om et pronomen $\mathrm{i}$ første eller anden person.

De ligheder og forskelle vi kan iagttage, er tankevækkende i forbindelse med forholdet mellem genealogi og typologi. Eftersom man kan spore pronominalsystemerne i fransk og italiensk tilbage til samme latinske ophav, og de danske personlige pronomener til et andet (fællesnordisk/-germansk) ophav, kunne man vente mange flere ligheder mellem fransk og italiensk end mellem disse sprog og dansk. Tidligere arbejder har dog vist at der er lighedspunkter mellem dansk og fransk (Kragh et al. 2014), og man kunne måske også hvad angår paratagmer, forvente lighed mellem disse to sprog. Denne hypotese vil vi afprøve i det følgende.

I typologisk perspektiv er det i det hele taget interessant at de tre sprog alle lever op til Sigurðssons betegnelse 'kasusfattige' sprog, at inventaret af personlige pronomener i de tre sprog ligner hinanden meget, og at man så alligevel kan iagttage tydelige forskelle i distributionen.

De resultater vi fremlægger i denne artikel, er baseret på undersøgelser af data fra elektronisk tilgængelige korpora over standardskriftsprog på de tre sprog. Selvom fænomenet især er udbredt i talesprog, har vi valgt skriftssprogskorpora fordi disse er langt mere omfattende og også indeholder eksempler på forskellige gengivelser af talesprog. Dataudvælgelsen er dog ikke helt uproblematisk, idet der netop ved kasusvalget i de personlige pronomener er stærke normative kræfter på spil, især i dansk og italiensk. Dette foranlediger blandt andet en metodologisk diskussion om hvorvidt de fremsøgte data giver et retvisende billede af (forholdene i) de pågældende sprog. 


\section{Kasusrige versus kasusfattige sprog}

I en artikel om subjektsprædikativer i germanske sprog skelner Sigurðsson (2006) mellem (relativt) kasusrige og kasusfattige sprog:

- Kasusrige sprog: islandsk, færøsk, tysk, jiddisch

- Kasusfattige sprog: norsk, svensk, dansk, nordfrisisk, engelsk, vestfrisisk

Sigurðsson udtaler sig alene om germanske sprog, men idéen er også relevant i forhold til moderne romanske sprog, der i modsætning til latin og tidligere stadier af nogle af sprogene er kasusfattige.

Som det fremgår af Sigurðssons liste, er moderne dansk et kasusfattigt sprog. Der er syv pronomener som bøjes i to former, se tabel 1:

\begin{tabular}{|l|l|l|l|l|l|l|l|}
\hline & \multicolumn{4}{|l|}{ singularis } & pluralis & \\
\hline & $1 \mathrm{p}$ & $2 \mathrm{p}$ & $3 \mathrm{pm}$ & $3 \mathrm{pf}$ & $1 \mathrm{p}$ & $2 \mathrm{p}$ & $3 \mathrm{pmf}$ \\
\hline nominativ & jeg & du & han & hun & vi & I & de \\
\hline oblik & mig & dig & ham & hende & os & jer & dem \\
\hline
\end{tabular}

Tabel 1 Personlige pronomener i moderne dansk

Distributionen af de pronominale kasusformer følger ikke udelukkende klassiske, syntaktisk-semantiske principper, men reguleres også af informationsstrukturelle forhold (se fx Heltoft 1997; Jørgensen 2000).

At give en fuldstændig redegørelse for den informationsstrukturelt betingede kasusdistribution vil føre for vidt i denne artikel, men nogle få generelle træk kan nævnes:Jørgensen (2000: 105 f.; 160-194; 295-296) skriver således at et overordnet princip er at pronomener brugt i syntaktiske funktioner med affinitet til bagrundsinformation ( $\mathrm{fx}$ subjekt) står i nominativ, mens de med affinitet til fokus (fx objekter og prædikativer) står i oblik form. Heltoft (1997) karakteriserer yderligere subjektspronomener der alene bidrager til fastholdelse af diskursreferenten i teksten som 'anaforiske', og sådanne subjektspronomener står i nominativ (fx Han larmer); hvis et subjektspronomen specificeres af et adled, står det i stedet i oblik form (fx Ham derovre larmer). Af særlig relevans er det at man i dansk bruger oblik form ved pronomener i ekstraposition, dvs. en informationsstrukturel funktion hvor man fremhæver nominalet ved at sætte det på en plads umiddelbart til venstre eller til højre for sætningen, og lader et pronomen repræsentere leddet inden i sætningen (fx $\boldsymbol{H a m}$, han er da en varre slyngel.).

De to romanske sprog, fransk og italiensk, er i modsætning til deres fælles 
udgangspunkt, det kasusrige latin, begge kasusfattige. Til gengæld er der i udviklingen fra latin til de romanske sprog på både fransk og italiensk opstået en skelnen mellem betonede og ubetonede former af de personlige pronominer (se fx Schøsler \& Strudsholm 2013).

Således har vi i moderne fransk to sæt pronomener, et sæt ubundne (betonede) og et sæt bundne (ubetonede):

\begin{tabular}{|c|c|c|c|c|c|c|c|c|}
\hline & \multicolumn{4}{|c|}{ singularis } & \multicolumn{4}{|c|}{ pluralis } \\
\hline & $1 \mathrm{p}$ & $2 p$ & $3 \mathrm{pm}$ & $3 \mathrm{pf}$ & $1 \mathrm{p}$ & $2 p$ & $3 \mathrm{pm}$ & $3 \mathrm{pf}$ \\
\hline \multicolumn{9}{|c|}{ ubundne/betonede former } \\
\hline & $m o i$ & toi & lui & elle & nous & vous & eux & elles \\
\hline \multicolumn{9}{|c|}{ bundne/ubetonede former } \\
\hline nominativ & je & $t u$ & il & elle & \multirow{3}{*}{ nous } & \multirow{3}{*}{ vous } & ils & elles \\
\hline akkusativ & \multirow{2}{*}{ me } & \multirow{2}{*}{ te } & le & la & & & \multicolumn{2}{|l|}{ les } \\
\hline dativ & & & lui & & & & leur & \\
\hline
\end{tabular}

Tabel 2 Personlige pronomener i moderne fransk

Også i fransk bruges oblik form ved pronomener i ekstraposition, som genoptages af et tryksvagt pronomen inden i sætningen (fx $\boldsymbol{M o i}$, je ne sais pas ('Mig, jeg ved det ikke')).

Det samme gælder for moderne italiensk, hvor man dog må skelne mellem to former for standard.

Det paradigme vi ser i tabel 3, er i overensstemmelse med den normative grammatiks tradition.

\begin{tabular}{|c|c|c|c|c|c|c|c|c|}
\hline & \multicolumn{4}{|c|}{ singularis } & \multicolumn{4}{|c|}{ pluralis } \\
\hline & $1 \mathrm{p}$ & $2 \mathrm{p}$ & $3 \mathrm{pm}$ & $3 p f$ & $1 \mathrm{p}$ & $2 \mathrm{p}$ & $3 \mathrm{pm}$ & $3 \mathrm{pf}$ \\
\hline \multicolumn{9}{|c|}{ ubundne/betonede former } \\
\hline nominativ & io & $t u$ & $\begin{array}{l}\text { egli } \\
\text { esso }\end{array}$ & $\begin{array}{l}\text { ella } \\
\text { essa }\end{array}$ & \multirow[t]{2}{*}{ noi } & \multirow[t]{2}{*}{$v o i$} & essi & esse \\
\hline oblik & $m e$ & te & $\begin{array}{l}\text { lui } \\
\text { esso }\end{array}$ & $\begin{array}{l}\text { lei } \\
\text { essa }\end{array}$ & & & $\begin{array}{l}\text { loro } \\
\text { essi }\end{array}$ & $\begin{array}{l}\text { loro } \\
\text { esse }\end{array}$ \\
\hline \multicolumn{9}{|c|}{ bundne/ubetonede former } \\
\hline nominativ & \multicolumn{8}{|l|}{$\varnothing$} \\
\hline akkusativ & \multirow[t]{2}{*}{$m i$} & $t i$ & lo & la & \multirow[t]{2}{*}{$c i$} & \multirow[t]{2}{*}{$v i$} & $l i$ & le \\
\hline dativ & & & $g l i$ & le & & & \multicolumn{2}{|l|}{$g l i$} \\
\hline
\end{tabular}

Tabel 3 Personlige pronomener ifolge traditionel fremstilling af standarditaliensk

En række af formerne i tredje person er dog sjældne i talesprog og flere skriftssprogsvarianter; de anvendes fortrinsvis i videnskabeligt og bureau- 
kratisk sprog, og i overensstemmelse med nyere fremstillinger af italiensk grammatik som fx Cordin \& Calabrese (1988) og Salvi \& Vanelli (2004) kan man opstille et revideret paradigme som det fremgår af tabel 4 . Det er primært formerne i dette skema der er udgangspunkt for vores analyser.

\begin{tabular}{|l|l|l|l|l|l|l|l|l|}
\hline & \multicolumn{9}{|l|}{ singularis } & pluralis \\
\hline & $1 \mathrm{p}$ & $2 \mathrm{p}$ & $3 \mathrm{pm}$ & $3 \mathrm{pf}$ & $1 \mathrm{p}$ & $2 \mathrm{p}$ & $3 \mathrm{pm}$ & $3 \mathrm{pf}$ \\
\hline
\end{tabular}

Tabel 4 Personlige pronomener på moderne standarditaliensk

I moderne tid er dansk, fransk og italiensk kasusfattige i Sigurdssons forstand. De former vi kender i dag, har ligget nogenlunde fast i 600-700 år, og de forandringer der er sket i forhold til kasus, vedrører primært distributionen og kun i mindre grad forminventaret. I dansk er der syv personlige pronomener der bøjes i to kasus; sådan har det været siden 1400-tallet. Som vi har set, har fransk og italiensk hver især to sæt pronomener, de ubundne og de bundne, med særlige distributionsregler knyttet til hvert sæt. På fransk har kasusdistinktionen i de ubundne pronomener siden det 14. århundrede været neutraliseret, mens den er bevaret på italiensk. Vi vil i denne artikel fremlægge en korpusundersøgelse af hvordan disse forskellige forhold afspejles i moderne sprogbrug i paratagmer i de tre sprog.

\section{Paratagmer med personlige pronomener}

Fælles for de anvendte korpora er at de repræsenterer skriftsprog gældende for tiden omkring årtusindskiftet; detaljer gives ved beskrivelsen for de enkelte sprog. I de data der ligger til grund for artiklens undersøgelser, er der alene set på paratagmer hvor det fremsøgte pronomen står uden tilføjelser overhovedet. Derfor udelades følgende konstruktionstyper fra undersøgelsen (her angivet med danske eksempler): forekomster med selv (ham selv), med specificerende tilføjelser fx i form af en relativsætning (dem der leser Marvel) eller en anden specifikation (hende fra Fyn). Dette skyldes at vi betragter konstruktioner som disse som selvstændige strukturer med egne principper for kasusdistributionen. 
Der er som hovedprincip søgt på kombinationer med tre variable: 1) det pågældende pronomen, 2) kasusform og 3) rækkefølge, fx og jeg, jeg og, og mig, mig og osv. Det giver følgende kombinationsmuligheder (i tabel 5 vist med danske eksempler:

\begin{tabular}{|c|c|c|c|c|c|c|c|c|}
\hline & \multicolumn{2}{|l|}{$1 \mathrm{p}$} & \multicolumn{2}{|l|}{$2 p$} & \multicolumn{2}{|l|}{$3 \mathrm{pm}$} & \multicolumn{2}{|l|}{$3 \mathrm{pf}$} \\
\hline \multirow[t]{3}{*}{$\mathrm{sg}$} & $x$ og jeg & jeg og $x$ & $x \operatorname{og} d u$ & $d u \operatorname{og} x$ & $x$ og han & han og $x$ & x og hun & hun og $x$ \\
\hline & $x$ og mig & $\operatorname{mig} \operatorname{og} x$ & $x$ og dig & $\operatorname{dig} \operatorname{og} x$ & $x$ og ham & ham og $x$ & x og hende & hende og $x$ \\
\hline & \multicolumn{2}{|l|}{$1 \mathrm{p}$} & \multicolumn{2}{|l|}{$2 p$} & \multicolumn{4}{|l|}{$3 \mathrm{pmf}$} \\
\hline \multirow[t]{2}{*}{$\mathrm{pl}$} & $x \operatorname{og} v i$ & vi og $x$ & $x \operatorname{og} I$ & $\operatorname{Iog} x$ & $x$ og de & & de og $x$ & \\
\hline & $x$ og os & os og $x$ & $x$ og jer & jer og $x$ & $x$ og dem & & dem og $x$ & \\
\hline
\end{tabular}

Tabel 5 Sogestrenge med danske eksempler

Der er ikke fuldstændig parallelitet i søgemulighederne i de respektive korpora, men resultaterne er ikke desto mindre sammenlignelige. For det første har vi i alle tre korpora målrettet søgt efter de nævnte pronominalformer i kombination med konjunktionerne $\mathrm{og}$, et og $e$. For det andet har efterfølgende manuel sortering sikret at irrelevante hits (som fx forekomster hvor ogjeg indleder en ny sætning i stedet for at være en del af et nominalparatagme) er udeladt.

\subsection{Dansk}

Til grund for det danske analysemateriale er der foretaget søgninger i KorpusDK, et bredt sammensat korpus bestående af tekster fra tiden omkring 1990 og 2000. Korpussets størrelse er på 56 mio. løbende ord (jf. http:/ / ordnet.dk/korpusdk/fakta).

Kasusdistributionen er overvejende konservativ: Ved subjekter bruges nominativ, jf. eksempel (1), i andre funktioner bruges oblik form, som i eksempel (2). Der er undtagelser til dette, se eksempel (3) og (4), men de er ganske få.

(1) Jeanette og jeg tager en uge til London

(2) Vi fik dig og nogle andre til at skrive at nu var der bogudsalg

(3) Hvorfor tror du din mor og dig kommer op at skændes?

(4) CD kan sagtens hænge sammen uden far og jeg 
Dermed er materialet i en vis grad ude af trit med den praksis man kan observere i talt sprog og i visse uformelle skriftlige genrer 100-200 år tilbage i tiden, hvorefter et sideordnet pronomen kan stå i oblik form uanset syntaktisk funktion, og (i mindre omfang) i nominativ uanset syntaktisk funktion (jf. Mikkelsen 1975 [1911]: 238; Diderichsen 1987 [1946]: 110; Hansen 1965: 102 f; Hansen 1972; 1993: 57-62; Lundskær-Nielsen \& Holmes 2010 [1995]: 145; Jørgensen 2000: 165-166, 178-180; Parrott 2009; Hansen \& Heltoft 2011: 440; Schack 2013; Johannessen 2014). Ikke desto mindre er det dette korpus der ligger til grund for undersøgelsen, da det svarer til de vilkår der gælder for de franske og italienske data. Denne diskrepans mellem hvad man på den ene side har observeret i dansk sprogbrug i generationer, og på den anden side i hvilken grad dette afspejles i KorpusDK, er genstand for en selvstændig redegørelse i Jensen (2018). Se også afsnit 4.4.

Ved ekstraposition bruges enten oblik form eller nominativ (se mere herom $i$ afsnit 4.3 og 5):

(5) Vi elsker hinanden meget, Jeff og jeg

(6) De var ikke alene, Simon og Kasper og hende

(7) De og jeg, vi ville ikke bryde os om at nogen fandt på at kalde os noget så grimt som socialbedragere, ville vi vel?

(8) Michael Laudrup og mig, om vi tror vi kan vinde. Sik'n et spørgsmål

Der forekommer ganske få mismatch-eksempler; i sådanne tilfælde ser det ud til at rækkefølgen er nominativ efterfulgt af oblik (se mere herom i afsnit 4.3).

\subsection{Fransk}

Samtlige data er fundet i det elektroniske tekstkorpus Frantext (http:/ / www. frantext.fr). Der er søgt på alle tekster i den taggede del fra perioden 19802010 med undtagelse af poesi, ialt 89 tekster, 6.565.476 ord, og uddraget $i$ alt 819 forekomster af paratagmer.

På søgning efter paratagmer med det bundne/ubetonede subjektspronomen kombineret med et andet pronomen, et proprium eller et nominalsyntagme indledt af en possessiv artikel ${ }^{1}$ ( $\mathrm{fx}$ mon mari) fås stort set ingen

1. I den franske tradition skelnes mellem possessiv artikel som determinativ og possessivt pronomen. 
forekomster. Der er til gengæld fast brug af ubundet/betonet pronomen ved paratakse.

Rækkefølgen i den parataktiske konstruktion afhænger af hvilke grammatiske personer konstruktionen involverer. Når moi indgår, er der således en klar overvægt af eksempler hvor moi står til sidst, som i eksempel (9) og (10):

(9) Comment croyez-vous que Hitler et moi sommes parvenus au pouvoir? 'Hvordan tror I at Hitler og mig er kommet til magten?'

(10) Il est à cent lieues d'imaginer que toi et moi sommes journellement tentés 'Han er milevidt fra at forestille sig at dig og mig dagligt er fristede'

Når det sideordnede led er af typen possessiv artikel + substantiv, står moi derimod først som i eksempel (11):

(11) Tu sais que moi et ton père sommes de bons amis

'Du ved at mig og din far er gode venner'

Det er i det hele taget bemærkelsesværdigt at i alle forekomster hvor det sideordnede led er possessiv artikel + substantiv, står dette sidst, uanset om der tale om første, anden eller tredje person, jf. fx eksemplerne (11), (12):

Mais rien que toi et ta mère ne sachiez déjà depuis longtemps

'Men intet som dig og din mor ikke allerede havde vidst i lang tid'

Verbet kongruerer i person og tal med paratagmet. Hvis der er et pronomen i første person singularis eller pluralis i paratagmet, bøjes verbet i første person pluralis, som det ses i (13) og (14). Ofte genoptages det parataktiske subjekt med et samlende pronomen som nous i eksempel (13):

(13) Nous sommes ensemble, elle et nous, ses enfants

'Vi er sammen, hun/hende og vi/os, hans/hendes børn'

(14) Lui et moi prenons le virage en même temps, ...

'Ham og mig skifter kurs samtidigt, ...'

Hvis der ikke indgår et førstepersonspronomen i paratagmet, men derimod et pronomen $\mathrm{i}$ anden person, bøjes verbet $\mathrm{i}$ anden person pluralis:

(15) Joséphine et toi donnez prise aux sarcasmes 'Josephine og dig udsætter jer for sarkasme' 
Det vil med andre ord sige at der er et skel mellem på den ene side første og anden person og på den anden side tredje person. Dette illustrerer et skel mellem pronomener med iboende deiksis (første og anden person) over for pronomener i tredje person, der kan anvendes både anaforisk og deiktisk (Benveniste 1966: 228).

\subsection{Italiensk}

De italienske data stammer fra skriftssprogskorpusset CORIS/CODIS (http:// corpora.dslo.unibo.it/), der omfatter i alt ca. 130 mio. ord. Der er tale om prosatekster fra de seneste tyve år, og de giver et repræsentativt billede af italiensk sprog i dag.

I lighed med fransk er der fast brug af ubundne pronomener i paratagmer. I eksempel (16) ser vi sideordning af to nominativformer i subjektsfunktion. Tilsyneladende er rækkefølgen tilfældig, men i begge tilfælde kongruerer verbet i første person pluralis:

\section{Sposiamoci domattina, tu e io \\ 'Lad os gifte os i morgen, du og jeg'}

I subjektsfunktionen finder vi imidlertid ofte eksempler på mismatch, nemlig en blanding af nominativformer og oblikke former. Her er forskelle fra person til person. I kombinationen af første person singularis og anden person singularis ligger det helt fast med nominativformen $i o$ sideordnet med den oblikke form te, og det gælder såvel i subjektets umarkerede position før verbalet som i ekstraposition:

(17) Io e te ci intendiamo perché parliamo delle stesse cose

'Jeg og dig forstår hinanden fordi vi taler om de samme ting'

Ma non siamo amiche, io e te?

'Men er vi ikke venner, jeg og dig?'

Det samme gør sig gældende i paratagmer bestående af substantivsyntagmer og pronomen:

(19) Perché Andrea e te avete lasciato Milano?

'Hvorfor har Andrea og dig forladt Milano?'

(20) Maria, Giorgio e te siete arrivati tardi

'Maria, Giorgio og dig kom sent' 
Der er kun ganske få forekomster af rækkefølgen anden person i oblik form efterfulgt af første person i nominativ:

(21) Parla di vita e di morte come te ed io delle nostre piccole faccende quotidiane! 'Han taler om liv og død som dig og jeg om vores små dagligdags gøremål!'

I paratagmer uden for subjektsfunktionen vil begge personlige pronomener altid være i oblik form, men rækkefølgen kan variere:

\section{È un segreto fra te e me}

'Det er en hemmelighed mellem dig og mig'

È un segreto fra me e te e nessun'altro

'Det er en hemmelighed mellem mig og dig og ingen anden'

C'è troppa differenza tra me e lui

'Der er for stor forskel mellem mig og ham'

Tra lui e me ci sono legami invisibili

'Mellem ham og mig er der usynlige bånd'

Korpusundersøgelserne giver ingen eksempler på sideordning mellem egli/ ella og personligt pronomen eller anden nominal størrelse.

Ligesom på fransk er pronomenerne i første og anden person deiktiske, mens der i italiensk i tredje person skelnes mellem deiktiske (lui/lei) og anaforiske pronomener (egli/ella).

\section{Perspektivering og diskussion}

Efter gennemgangen af de undersøgte data i de tre sprog vender vi nu tilbage til det komparative aspekt. Hvad dette angår, er der nemlig adskilligt at bemærke; af interesse er især inventar (fransk og italiensk har to sæt pronomener, dansk har kun ét), kasusdistribution samt konstituenternes rækkefølge i paratagmer. Det komparative blik på disse forhold giver blandt andet anledning til diskussion af forholdet mellem typologi og genealogi og af forholdet mellem norm og usus.

\subsection{Inventar}

Som tidligere anført har fransk og italiensk to sæt pronomener, ubundne og bundne; det har dansk ikke. Fransk og italiensk er altså ens på dette punkt i sammenligning med dansk. Pronomenerne i fransk og italiensk har samme 
etymologiske ophav og ligner hinanden meget morfologisk, men alligevel forvaltes de forskelligt.

Fransk har kun ét sæt ubundne pronomener, hvilket bevirker at det faktisk ikke giver mening at tale om kasusvalg. Formerne er kasusneutrale og har morfologisk sammenfald med de oprindeligt oblikke former. Heroverfor står italiensk som har to sæt ubundne pronomener, ét i nominativ og ét i oblik form. Denne forskel i de italienske pronomener er især markant i den traditionelle skriftssprogsnorm, hvor der konsekvent skelnes mellem brug af nominativformerne som subjekt og de oblikke former i andre ledfunktioner (se tabel 3). I moderne standarditaliensk er denne kasusdistribution reduceret til første og anden person singularis, mens kasusforskellen er neutraliseret i tredje person både singularis og pluralis (se tabel 4). I italiensk klassificeres subjektspronomenerne i tredje person singularis, egli og ella, traditionelt som betonede pronomener. De er dog i modsætning til de øvrige subjektsspronomener ikke ubundne, idet de er bundet til subjektets kanoniske plads før verbalet, jf. Maiden (1998: 180), som anvender betegnelsen 'semiklitisk'.

\subsection{Rakkefølge i paratagmer}

I paratagmer hvor der indgår et personligt pronomen, vil der naturligt være en rækkefølge af konstituenterne. Materialet fordeler sig på to typer paratagmer, nemlig dem der består af et pronomen og et nominalt led der ikke er et personligt pronomen (min mand og jeg), samt dem der består af to (eller flere) personlige pronomener (ham og hende). Vi kan se visse mønstre som trækker i samme retning i alle tre sprog, og andre mønstre der er sprogspecifikke. Rækkefølgen afhænger bl.a. af hvilke personer der indgår i paratagmet.

For dansks vedkommende er der stor forskel på om der indgår et pronomen i første person singularis eller ej. Hvis paratagmet indeholder jeg eller mig, står dette pronomen typisk til sidst. Der er 4994 paratagmer med kombinationen og jeg/mig mod 938 med kombinationen jeg/mig og, hvilket vil sige at der er cirka 5 gange så mange med pronomenet til sidst som med pronomenet forrest. Ved alle de andre pronomener forholder det sig omvendt. Der er 7381 paratagmer med pronomenet først, mod 605 med pronomenet til sidst. Der er altså mere end 10 gange så mange med pronomenet først snarere end sidst i paratagmet. ${ }^{2}$

På fransk er der tilsyneladende ret klare tendenser når det gælder ræk-

2. Der er stort set ikke nogen forekomster med $\mathrm{g}$ de/dem uden yderligere specifikation når de/dem står sidst i et paratagme. 
kefølgen i paratagmet. Når paratagmet består af et personligt pronomen sideordnet med en anden type nominalt led, er tendensen at moi står til sidst (454 eksempler ud af $\mathrm{i}$ alt 469 forekomster med moi), undtagen når det sideordnede led er af typen possessiv artikel + substantiv. Her er der en meget klar tendens til at den possessive artikel + substantiv står sidst i paratagmet, uanset hvilket personligt pronomen det kombineres med, idet det er tilfældet i samtlige 46 eksempler. Når et personligt pronomen kombineres med et proprium, står pronomenet oftest sidst i paratagmet. Når paratagmet udelukkende består af personlige pronomener står toi, lui og elle typisk først; det gælder også for vous, i modsætning til moi og nous, der normalt optræder til sidst i paratagmet.

På italiensk ses der i forbindelse med sideordning mellem et personligt pronomen og en anden nominal størrelse ingen tydelige tendenser til en fast rækkefølge. I paratagmer bestående af personlige pronomener i første og anden person singularis er rækkefølgen tu e io så godt som fast når der anvendes to former i nominativ (151 eksempler, men kun fem eksempler på io e tu), mens rækkefølgen i mismatch-eksempler er den omvendte, altså io e te (191 eksempler over for to eksempler på te e io). I kombinationen første person singularis sideordnet med tredje person singularis er der en overvægt af eksempler hvor første person kommer først: rækkefølgen io e lui/ lei dækker således ca. to tredjedele af eksemplerne, og lui/lei e io den sidste tredjedel. I tredje person finder vi altid de oprindeligt oblikke former (lui og lei) i paratagmer idet subjektspronomenerne (egli og ella) er verbalbundne og ikke kan anvendes i paratagmer.

\subsection{Mismatch og rakkefølge}

Som tidligere anført har dansk og italiensk mulighed for mismatch, det har fransk ikke (se også Benveniste 1966: 198). På grund af de særlige forhold i fransk kan man nemlig slet ikke forestille sig mismatch-eksempler idet der reelt ikke er nogen valgmulighed mellem to former.

I det danske materiale forekommer der kun tre mismatch-eksempler. I disse er rækkefølgen nominativ efterfulgt af oblik form:

(26) De havde misforstået alt, hun og ham - troet, at det nye brød frem gennem dem

(27) et lille bevis over for andre på at de hørte sammen, han og hende

(28) De selv, han og hende, fyldte flere maskiner, og satte sig derpå for at vente på vasken 
Dog er forholdene lidt anderledes i 1. person singularis (og jeg). Se mere herom i afsnit 4.4 .

I italiensk er det i visse tilfælde snarere reglen end undtagelsen at have en blanding af kasus i parataktiske forbindelser. Det gælder i kombinationen første person singularis og anden person singularis, hvor første person altid står i nominativ (io) og anden person i oblik form (te), jf. eksempel (17) og (18). De italienske tredjepersonspronomener i nominativ er verbalbundne, og det er ikke muligt at finde dem i et paratagme. I stedet anvendes de oprindeligt oblikke former, også som subjekt, jf. eksempel (29) og (30). Disse kan indgå i paratagmer af typen io e lui/lei, tu e lui/lei, og selvom lui og lei på mange punkter har fortrængt de oprindelige subjektspronomener, må disse kombinationer formelt opfattes som mismatch:

Non volevo che restassimo io e lui soltanto [...]

'Jeg ville ikke at jeg og ham blev alene tilbage'

Ma anche se tu e lei siete sullo stesso pianeta [...]

'Men selv om du og hende befinder jer på den samme planet [...]'

\subsection{Norm og usus og rakkefølge}

Som nævnt i indledningen har der traditionelt været stærke normerende kræfter på spil i forbindelse med distributionen af de personlige pronomener. Dette afspejler sig tilsyneladende ved rækkefølgen af pronomener i paratagmer i de tre sprog. Standardgrammatikkerne siger generelt ikke noget om rækkefølgen af ubundne pronomener i paratagmer, men vi kan konstatere visse tendenser der afspejler sociale høllighedsnormer.

I afsnit 4.2 blev det nævnt at der i dansk er en stor overvægt af forekomster hvor et pronomen i første person singularis er placeret sidst i paratagmet. Dette hænger formodentlig sammen med at man fra barnsben af sine omgivelser (skole, hjem, lokalmiljø) lærer at det er uhøfligt at nævne sig selv først. Dette er en udmøntning af en mere generel adfærdsregel om at man ikke må mase sig frem foran andre, fx ved spisebordet, på vej gennem en dør eller i køen i supermarkedet. Denne adfærdsregel har afsmittende effekt på det sproglige, hvor det er helt almindeligt at håndhæve at det mest høflige er at nævne andre før sig selv. Dette kan altså forklare den store forskel på rækkefølgen i danske paratagmer nævnt i afsnit 4.3, hvor ogjeg/ mig er langt hyppigere end jeg/mig og, mens det forholder sig omvendt ved alle andre pronomener. Samme tendens findes i fransk, hvor det ifølge 
Sandfeld (1970 [1928]: 95) er "god tone at den der taler nævner sig selv til sidst" (vores oversættelse), hvilket dog ikke altid respekteres i uformelt sprog. Her spiller hierarkiske forhold dog også ind, således at fx moi et un domestique ('mig og et tyende') tilsidesætter den gode tone.

Endnu en effekt af opdragelse og normering finder man i forbindelse med selve strengen og jeg i dansk. I hvert fald siden slutningen af 1800-tallet (jf. Jensen 2018) har man kunnet bruge oblik form i paratagmer. Det afstedkommer dels variation (hvor både nominativ og oblik form kan bruges i subjektsfunktion), dels - og måske netop på grund deraf - en normkonflikt, hvor man i visse kredse anser det for finere at gøre det oprindelige, nemlig kun at bruge nominativ i subjektsfunktion. Hvis man som barn siger mig og Peter, bliver man ofte rettet til at sige Peter og jeg. Rettelsen i kasus skyldes normkonflikten, rettelsen i rækkefølge skyldes den ovenfor nævnte adfærdsregel der kræver at man ikke sætter sig selv før andre.

Disse rettelser resulterer i at og jeg af nogle kan opfattes som den eneste rigtige måde at danne paratagmer på hvori der indgår et pronomen i første person singularis. I løbet af 1900-tallet har man kunnet iagttage at denne form er begyndt at vise sig i nominaler der ikke fungerer som subjekt. Eksempel (4) ovenfor hvor og jeg optræder i en styrelse (uden far og jeg), er mindre usædvanligt end man kunne tro (se også Jensen 2018). Også dette udsættes for normeringsbestræbelser idet nogle anser og jeg uden for subjektsfunktion for hyperkorrektion og dårligt dansk.

I fransk er det ifølge Togeby (1974: 106) netop i forbindelse med paratagmer at brugen af oblik form som subjekt først manifesterer sig; dette sker fra midten af det 12. århundrede. Nye data bekræfter at der på fransk ikke er samme mulighed for mismatch som på dansk og italiensk. Der er dog i datamaterialet fundet to eksempler hvor der ikke er anvendt ubundne pronomener, i begge tilfælde ved sidestilling af to pronomener og i begge tilfælde med pronomener i tredje person. Dette er værd at bemærke da en forekomst med det bundne første persons pronomen je er endnu mere utænkelig, idet man ikke kan betone en stavelse der indeholder svagtryksvokalen /ə/.

Car justement, [...], il et elle en ont marre, ... 'For netop, han og hun er trætte af det, ...'

Ils et elles ne peuvent pas faire autrement...

'De (maskulinum) og de (femininum) kan ikke gøre andet...' 
Disse eksempler må siges at være undtagelser, og da femininumsformen af det bundne pronomen både i singularis (31) og pluralis (32) er identisk med det ubundne, er det kun pronomenerne i maskulinum der er entydigt bundne. Principielt kan det derfor ikke udelukkes at der her er tale om mismatch, men det kan ikke afgøres. Under alle omstændigheder står disse to eksempler alene, og eftersom brugen af den ubundne form har ligget fast $\mathrm{i}$ adskillige århundreder, er der næppe anledning til at tolke disse to forekomster som eksempler på hyperkorrektion.

I italiensk foreskriver den traditionelle italienske skriftsprogsnorm ganske vist brug af formerne i nominativ i subjekt, men ikke desto mindre ses der allerede i 1200-tallet en tendens til at benytte oblikke former som subjekt, især i tredje person singularis (lui/lei i stedet for egli/ella), når subjektet ikke står på sin kanoniske plads umiddelbart før en finit verbalform (Egerland \& Cardinaletti 2010: 405). Senere, i 1400-tallet, ses den samme tendens $\mathrm{i}$ anden person singularis (te i stedet for $t u$ ). Det ses bl.a. som subjekt for infinitte verbalformer, som altid er efterstillet, i elliptiske konstruktioner når subjektet står isoleret (dvs. løsrevet fra verbalformen) og i sammenligninger. Den norm der foreskriver egli og ella som subjekt, blev fastlagt i begyndelsen af 1500-tallet og var gældende langt op i tiden. Et opgør med denne norm finder vi hos forfatteren Alessandro Manzoni, der i forbindelse med sin omskrivning af I promessi sposi 1840 næsten konsekvent udskiftede forekomster af egli og ella med henholdsvis lui og lei. I moderne italiensk kan egli og ella kun bruges som subjekt i positionen umiddelbart før en finit verbalform, og de kan ikke som andre subjektspronomener adskilles fra verbalformen af fx en relativsætning. Endvidere kan de ikke anvendes isoleret (uden en verbalform), og de kan ikke indgå i paratagmer med et andet nominalsyntagme. I modsætning til lui og lei kan de ikke bruges med deiktisk reference. Vi kan i forbindelse med subjektspronomenerne egli og ella, senere også $t u$, tale om en svækkelse hvor de har mistet deres status som betonede/ubundne størrelser, men til gengæld fået en fast placering lige før verbalet; med Maidens ord har de fået karakter af at være semiklitiske (1998: 176; 180). På moderne standarditaliensk betragtes det ikke længere som et brud på normen at bruge de oblikke former i tredje person som subjekt.

\section{Konklusion: Hvor er den franske forbindelse?}

Vi havde som udgangspunkt ventet at finde markante lighedspunkter mellem dansk og fransk i brugen af personlige pronomener. I tidligere arbejder har vi set at dansk og fransk på visse punkter ligner hinanden, 
mens italiensk skiller sig ud; for eksempel har både dansk og fransk udviklet obligatorisk subjekt, mens italiensk ikke har (Kragh et al. 2014). At der skulle være ligheder mellem fransk og dansk sprogstruktur, er i øvrigt ikke en fremmed tanke. Allerede for over 100 år siden skrev Lefolii (1871: 90) således at der "i det hele taget i Sproget [er] en Bevægelse hen imod at bruge Afhængighedsformen som det franske Sprogs pronoms absolus. Sterkest træder dette frem, naar det i jydsk Tale ofte hedder: Min Broder og mig eller mig og min Broder kom ved vor Farbroders Død $i$ Besiddelse af en stor Formue". Også Mikkelsen henviste til fransk moi når han ville anskueliggøre hvordan dansk mig bruges ved subjektsprædikativer (Mikkelsen 1894: 321) og under visse omstændigheder ved subjekter (Mikkelsen 1975 [1911]: 238). Jørgensen (2017) kalder et af sine igangværende projekter om morfosyntaktiske ligheder i brugen af personlige pronomener i dansk og fransk for "The French Connection".

Vi havde derfor forventet at dansk og fransk i højere grad fulgte hinanden hvad angår kasusdistributionen i paratagmer. Vi kan se at man i franske paratagmer konsekvent bruger de ubundne pronomener, moi, toi etc. I dansk forholder det sig ikke sådan: Her bruger man til dels nominativ, til dels oblik form. Oven i købet kan man i dansk finde eksempler på såkaldt mismatch, det kan man ikke i fransk, men til gengæld godt i italiensk. Vi havde også ventet at danske paratagmer i ekstraposition ville stå i oblik form, ligesom andre (ikke-parataktiske) personlige pronomener i denne position - og ligesom i fransk, jf. afsnit 2. Men også her forholder det sig anderledes: I dansk finder man både nominativ og oblik form i paratagmer, jf. eksemplerne (5) - (8); det samme gør sig gældende for italiensk, jf. eksemplerne (17) - (21). Den manglende parallelitet på disse punkter kan skyldes at dansk og fransk trods alt er mindre sammenlignelige end ellers antaget. Dansk har et sæt personlige pronomener med kasusbøjning i to former og tilhørende kasusdistribution, mens fransk har to sæt personlige pronomener, hvoraf det sæt der bruges ved paratagmer, kun findes i en form. I sammenligning hermed kan vi se at italiensk ligesom fransk har to sæt personlige pronomener men med kasusbøjning ligesom dansk; dette giver mulighed for mismatch. Der er overensstemmelse mellem fransk og italiensk med hensyn til fordelingen af de to sæt pronomener, men mens kasusdistinktionen på fransk er neutraliseret, opretholdes der på italiensk en delvis skelnen mellem nominativ og oblik kasus.

Undersøgelserne har altså vist at der ikke var den forventede forbindelse mellem dansk og fransk, men at der til gengæld er en bevægelse i italiensk 
på vej mod den franske model med kasusneutralisering i forbindelse med de ubundne/betonede pronomener. Desuden er der en klar forbindelse mellem dansk og italiensk i muligheden for mismatch.

\section{Om forfatterne}

Eva Skafte Jensen, dr. phil., seniorforsker, Dansk Sprognævn.

Kirsten A. Jeppesen Kragh, lektor, ph.d., Institut for Engelsk, Germansk og Romansk, Københavns Universitet.

Erling Strudsholm, lektor, ph. d., Institut for Engelsk, Germansk og Romansk, Københavns Universitet.

\section{Litteratur}

Benveniste, É. (1966): Problèmes de linguistique générale 1. Paris: Éditions Gallimard.

Cordin, P. \& Calabrese, A. (1988): I pronomi personali. I: Grande grammatica italiana di consultazione 1. Renzi, L. (red.). Bologna: Il Mulino, 535-592.

Diderichsen, P. 1987 [1946]: Elementer Dansk Grammatik (3. udg.). København: Gyldendal.

Diderichsen, P. (1952): De tre hovedarter af grammatisk forbindelse. Bidrag til en analyse af lingvistikkens metasprog. I: Festskrift til L. L. Hammerich. Bach, H. (red.). København: Gad, 89-104.

Egerland, V. \& Cardinaletti, A. (2010): I pronomi personali e riflessivi. I: Grammatica dell'italiano antico 1. Salvi, G. \& Renzi, L. (red.). Bologna: Il Mulino, 401-467.

Hansen, Aa. (1965): Vort vanskelige sprog (2. udg.). København: Grafisk forlag. Hansen, E. (1972): Dr. Jekyll og Mr. Hyde i Dansk Grammatik. En filologisk skitse. Papir I, bunke 4 (genoptrykt i Gleden ved grammatik. Udvalgte artikler og afhandlinger 2001, 98-110), 1-13.

Hansen, E. (1993): Rigtigt dansk (2. udg.). København: Hans Reitzels Forlag. Hansen, E. \& L. Heltoft (201 1): Grammatik over det danske sprog. København: Det Danske Sprog- og Litteraturselskab \& Odense: Syddansk Universitetsforlag.

Heltoft, L. (1997): Hvem opslugte hvo. Et bidrag til beskrivelsen af det danske kasussystems udvikling. I: Ord, Sprog oc artige Dict. Festskrift til Poul Lindegård Hjorth. Lundgreen-Nielsen, F., Nielsen, M.A. \& Sørensen, J.K. (red.). København: Universitets-Jubilæets danske Samfund \& C. A. Reitzel, 227-256. 
Jensen, E.S. (2018): Norm, usus og korpus. I: Dansk til det 21. Arhundrede - sprog og samfund. Christensen, T.K., Fogtmann, C., Jensen, T.J., Karrebæk, M.S., Maegaard, M., Pharao, N. \& Quist, P. (red.). København: U Press, 171-182.

Johannessen, J.B. (2014): Case in coordinated conjuncts. Nordic Atlas of Language Structures Fournal 1, 18-27.

Jørgensen, H. (2000): Studien zur Morphologie und Syntax der festlandskandinavischen Personalpronomina - mit besonderer Berücksichtigung des Dänischen. Århus: Aarhus University Press.

Jørgensen, H. (2017): The French Connection - analogies in morphology and syntax between French and Mainland Scandinavian personal pronouns. Paper presented at the Workshop on case-impowerished Germanic.

Kragh, K.J., Jensen, E.S. \& Strudsholm, E. (2014): Med og uden subjekt. I: Ny forskning i grammatik 21. Birkelund, M., Fernandéz, S.S., Jørgensen, H., Kratschmer, A. \& Nølke, H. (red.). Odense: Institut for Sprog og Kommunikation, Syddansk Universitet, 143-162.

Lefolii, H.H. (1871): Sproglerens Grundbegreber, som de komme til Udtryk i Modersmaalets Sprogform. Bidrag til dansk Sproglere. Kjøbenhavn: C.A. Reitzels Forlag.

Lundskær-Nielsen, T. \& P. Holmes 2010 [1995]: Danish - a comprehensive grammar (2. udg.). London, New York: Routledge.

Maiden, M. (1998): Storia linguistica dell'italiano. Bologna: Il Mulino.

Mikkelsen, K. (1894): Dansk Sproglere, med sproghistoriske Tillag: Haandbog for Larere og Viderekomne. København: Lehmann \& Stage.

Mikkelsen, K. 1975 [1911]: Dansk ordföjningslere med sproghistoriske tillag (genoptrykt og forsynet med index). København: Hans Reitzels Forlag.

Parrott, J.K. (2009): Danish vestigal case and the acquisition of vocabulary in distributed morphology. Biolinguistics 3, 270-304.

Salvi, G. \& Vanelli, L. (2004): Nuova grammatica italiana. Bologna: Il Mulino.

Sandfeld, K. (1970 [1928]): Syntaxe du français contemporain. Les pronoms (1). Paris: Éditions Champion.

Schack, J. (2013): Dig og mig og vi to. Synspunkter på kasus i moderne dansk. NyS. Nydanske sprogstudier 45, 48-72.

Schøsler, L. \& Strudsholm, E. (2013): Preservation, modification, and innovation. Paradigmatic reorganisation of the system of personal pronouns - from Latin into Modern Italian. I: Deixis and pronouns in Romance languages. Kragh, K. J. \& Lindschouw, J. (red.). Amsterdam, Philadelphia: Benjamins, 49-68. 
Sigurðsson, H.Á. (2006): The Nom/Acc alternation in Germanic. I: Comparative studies in germanic syntax. Hartmann, J. \& Molnárfi, L. (red.). Amsterdam, Philadelphia: Benjamins, 15-50.

Togeby, K. (1974): Précis historique de grammaire française. København: Akademisk Forlag. 